\title{
The Root of Sin: An Analysis on the Social and Economic Situation Reflected from To Kill a Mockingbird
}

\author{
Youwen Hu, Min Zhou* \\ Zhejiang Ocean University, Zhoushan, China
}

*Corresponding Author: Min Zhou, Zhejiang Ocean University, Zhoushan, China

\begin{abstract}
Since the birth of To Kill a Mockingbird, there have been researches and criticism on the analysis of racism, feminism and symbolic meaning embodied in it. As the novel is set in the nineteen thirties, it illustrates the years of the Great Depression between the lines and words, which was one of the severest economic recessions throughout the history, continuing for several years from 1929 to 1939. This book is not a documentary novel, but it is not difficult for readers to trace some economic and social hints of that time and even their influences to the characters and plots of the story. This paper is attempting to analyze and explore the possible reasons for Tom Robinson's impoverished life and his false charge in terms of racism and economy, to demonstrate the root of his inevitable misery fate, offering a new interpretation path and reading interest of the novel.
\end{abstract}

Keywords: Economics. Racism, To Kill a Mockingbird

\section{INTRODUCTION}

Nelle Harper Lee (1926.4.28 -2016.2.19) was an American writer, who was broadly famous for To Kill a Mockingbird, the publishing date of which is 1960. The book was a real hit and it won the 1961 Pulitzer Prize. Since then the book came to be known as a literary classic in the American history.

The birthplace of Nelle Harper Lee was Monroeville, which was a small, ordinary and quiet town in Alabama. In a number of respects, the town of Monroeville and the town of Maycomb, backdrop of To Kill a Mockingbird were much alike. Apart from the backdrop, she also found inspiration from the people around her, for instance, her father, a lawyer, was considered as the prototype of the fictional character Atticus Finch, who was also a lawyer; and her childhood friend Truman Capote who was a writer was also thought to be a source of inspiration for the character named Dill. Despite these details, Lee holds the view that To Kill a Mockingbird was not a description of her childhood; instead, it's just a typical Southern town.

In addition to the book's setting and character that have a close bearing on the events happened on the Lee's childhood, the main plot of the book may also have something to do with her childhood. When Lee was young, there was an outrageously unfair charge against nine black people who stands accused of criminal assault of two white women near Scottsboro, Alabama despite the fact there was no incontestable evidence that the crime was actually committed and the testimonies given by the alleged victims, after a number of appeals, became dubious and suspicious. A number of eminent lawyers and some American citizens thought of this conviction as bogus and brought about by racism and prejudice. This case bears a striking resemblance to the one that occurred in the novel, which was also motivated by racism and prejudice so it is not difficult to tell that this dirty case functioned as an initial inspiration for the unfair trial in the Lee's novel, forging an initial but indistinct conception for her fiction.

In To Kill a Mockingbird, Lee mainly depicts a similar case that a black man Tom Robinson has been charged with rape despite the fact that no direct evidence was against him. Regardless of people's disgusting gossip, the white lawyer Atticus Finch still spared no efforts to defend his innocence and eventually lost the case.

Since the birth of the novel, there have been researches and criticism on the analysis of racism, feminism and symbolic meaning embodied in it. As the novel is set in the nineteen thirties, it 
illustrates the years of the Great Depression between the lines and words, which was one of the severest economic recessions throughout the history, continuing for several years from 1929 to 1939. This book is not a documentary novel, but it is not difficult for readers to trace some economic and social hints of that time and even their influences to the characters and plots of the story. This paper is attempting to analyze and explore the possible reasons for Tom Robinson's impoverished life and his false charge in terms of racism and economy, to demonstrate the root of his inevitable misery fate, offering a new interpretation path and reading interest of the novel.

\section{An ANALYSIS ON THE Social Situation}

\subsection{Historical Reasons for Racism towards African Americans}

Historically, black people had been trafficked from other continents to America, since then they had worked as slaves for whites, and even if the slavery had been abolished, the view that black people were inferior to whites was deeply ingrained in most people, which serves as a cause for the reason why many of white Americans discriminated against black people at the time.

The history of black people being treated as slaves can date back to the development of slavery. In 15th century Portuguese colonists commenced the first slave trade, and then due to huge economic benefits other countries scrambled to imitate. The British set up a "Guinean company" in 1585, "Barbary, Moroccan Company" company in 1588 for slave trade. In the 1618, James I chartered the "London merchants Africa trade company". Later in 1660, "British Royal Africa Trade" was established, which was restructured as "Royal Africa company" and was governed by James, Duke of York, who was the brother of Charles II. Since then, black trade had been completely commercialized. In 1619, about 20 black men were brought to Jamestown, the United States, by Dutch people. Then in the subsequent years, British companies kept exporting black slaves to America due to huge profits. From then on, the word "slave" was tied to black people.

The colonies in United States began to make laws in relation to slavery around the 1940s. At first, blacks could earn money through their own efforts to redeem themselves as free men, but later they became the private property of the white people. In Virginia colonies which were first colonized by Britain, black people were seen as contract laborers at the beginning of their entry into the Virginia colonies. They were beginning to be reduced to slaves in the $1650 \mathrm{~s}$. It is widely accepted in the current American academic circles that the slavery law in the 1660s officially confirmed the legitimacy of slavery, (Zhang Juguo, 2006) which contributed to the unprecedented restricted freedom of black people. More and more slave owners saw them as their own property, freely selling them or renting them like tools to others to make profits. From 17th century to the end of slavery, a number of scholars believe that the history of being ruled as slaves was the root of racism.

After the Civil War, the United States liberated the black slaves and protected their civil rights through constitutional amendments, but despite the abolition of slavery, the long-established discriminatory attitude towards blacks in American history could not be eliminated at once. (Zhao Mingming, 2017)

\subsection{Evidence of Racism from Text towards African Americans}

Therefore in To Kill a Mockingbird, it is not unusual for Tom Robinson, as a black people, be an easy object of racism and discrimination. By analyzing some words and depictions in Lee's work, we could further understand to what extent he is discriminated against.

In an open court where Mr. Ewell, who's a typical white man who deeply hates black people, was giving his testimony, '-I seen that black nigger yonder ruttin' on my Mayella.'”(Harper Lee, 1960, P231) While Ewell is attesting in court, it can easily be seen that he is trying crazily to differentiate himself from the black. The word "nigger" is a commonly insulting slur towards the black people. However, speaking out "black nigger" with the unnecessary word "black" implies that all he sees is the black skin of Tom Robinson. At the same time, the situation of racism is even compounded as Ewell refuses to treat Tom as a human being in that he does not call Tom by his name or even the personal pronoun "he", but rather he chooses to adopt the word "rutting" , which is in general used to describe animals, to degrade Tom as an animal, a derogatory racial remarks which can be found when later he describes the black people's settlements as "that nigger- nest down yonder"(Harper Lee, 1960, P234). 
There is another subtle word "nigger-lover" which is not meant for insulting blacks but for some good-natured white people who are willing to treat blacks fairly and lend a hand to them at times. Atticus, the protagonist's father, is one of them, and he gave his interpretation concerning "niggerlover". "Nigger-lover is just one of those terms that don't mean anything _ like snot-nose. It's hard to explain-ignorant, trashy people use it when they think somebody's favoring Negroes over and above themselves. It's slipped into usage with some people like ourselves, when they want a common, ugly term to label somebody."(Harper Lee, 1960, P144) On the whole, the connotations of the word "nigger lover" can roughly be summarized in two dimensions. Firstly, the word is coined to humiliate those including the lawyer Atticus who choose to reject the racism that seems commonplace to others in the town. Secondly, the language is used to subtly classify the town residents into three categories: a white supremacist group who are dismissive of black people and those who are close to them; people like Atticus, called "nigger lovers" who are willing to fight for equal right for all the people: the black people, the bottom of the social hierarchy. As Atticus suggests, the utilization of the word of "nigger" or "nigger-lovers" is a typical example of the ingrained racism and prejudice in the people's minds of the south. "nigger lover", intended to be an humiliation by others is also mixed with the hopes that Atticus will submit to their racist beliefs, which in turn can also indicates that the racism was so deeply rooted in the most white that they can't even tolerate other white people's being nice and fair to black people.

Apart from Ewell's words that show extreme racism towards Tom Robinson, it is revealing to explore how the racism towards the black is in a wider and social context. Behind the statement that Atticus the lawyer gave in court lies a stunning reality concerning the racism in nearly all citizens of Maycomb, he said in court,

"What was the evidence of her offense? Tom Robinson, a human being. She must put Tom Robinson away from her. Tom Robinson was her daily reminder of what she did. What did she do? She tempted a Negro. She was white, and she tempted a Negro. She did something that in our society is unspeakable: she kissed a black man. Not an old uncle, but a strong young Negro man. No code mattered to her before she broke it, but it came crashing down on her afterwards."(Harper Lee, 1960, P272)

This statement demonstrates a widespread and stereotyped racist idea among the most of the town's people. That is whether it is undeniable truth or not, they have a unfairly natural inclination to believe that a white women was raped by a black man and refuse to believe that woman will choose to kiss a black man on her own initiative. People prefer to assume that Tome raped that woman just because of the false prejudice that it is something black people ,who in their minds are mere animals, do though It is apparent that the possible effect of rape is more serious than just a kiss.

And in his closing remark, he also incisively pointed out what the public opinions were about black people.

"In the cynical confidence that their testimony would not be doubted, confident that you gentlemen would go along with them on the assumption-the evil assumption-that all Negros lie, that all Negroes are basically immoral beings, that all Negro men are not to be trusted around our women, an assumption one associates with minds of their caliber...There is not a person in this courtroom who has never told a lie, who has never done an immoral thing, and there is no man living who has never looked upon a women without desire."(Harper Lee, 1960, P273)

He goes straight to the heart of the matter and exposes the racial stereotypes that cause the divide between the black and the white by arguing that the very evidence of the Tom's crime is the blackness. it doesn't matter whether he committed the crime or not, it matters that he is merely black. And he pointed out that that everyone, more or less, told a lie or did some immoral things in his or her life, and suggests that wrongdoings are not limited to the black. In essence, he is hinting that both the races are equally of capability to commit crime and that the one race is not more or less superior to the other

In these depiction and analysis, we can perceive that the discrimination against blacks in this small town has gone deep into the marrow of most of whites, who are even demonizing and distorting them, because their ancestors were slaves since they entered America. They think Slaves are cheap and unreliable. Slaves represent war, crime and all evil things. They believe that all blacks lie, are born 
evil, and are all unreliable for all women. (Meng Deming, 2017), and after looking into the historical reasons for racism, it's not difficult to understand the most of white people's pathological racism and hatred towards Tom Robinson in Maycomb as he was convicted of raping despite there's obvious evidence that can prove him innocent. So for Tom Robinson, as a black man, he has no way to escape from unfair conviction although Atticus's powerful statements that seems incontrovertible and attempt to awaken the white people's inner good and integrity. In brief it seems that he was doomed to failure from the start since he was involved in a law case with white people.

\section{An ANALYSIS ON THE ECONOMIC SitUATION OF THAT Time}

\subsection{The and Reasons for the Economic Status of that Time}

The Great Depression was one of the severest economic recessions throughout the history, continuing for several years from 1929 to 1939. In America the Great Depression disabled the administration of Herbert Hoover and prompted the race of Franklin D. Roosevelt in 1932. Some financial analysts and history specialists contend that it is the securities exchange crash of October 24, 1929 that gave rise to economic downturn. In spite of that, as a matter of fact, not just one cause, there are a number of factors that contributed to or worsen the Great Depression.

Financial exchange Crash of 1929: It is commonly known as "Dark Tuesday". But in reality this disaster is not the only origin for the Great Depression, actually it was also not the first crash in October, 1929. The market rose to record highs during the summer; however it started to go down in September. On 1929.10.24, the market plunged immediately into chaos and people were in extreme despair after the stock index dropped an appalling 40 percentage point. As the disaster began to unfold, it was beyond the ability of the policy-makers and financial experts to keep the depression in check. Simply in five days after the market broke down it lost 12 percent of its capital value and the investment, which was worth 14 billion evaporated. After two months, over 40 billion dollars were wiped out from the investors. America was starting to go through the Great depression as the economy was in dire and bleak conditions.

Figure 1 shows how stock costs climbed relentlessly starting around 1918 (with minor changes all through) and topped pointedly in 1928 and 1928. You can see a sharp decrease around the finish of 1929. Stock costs started to decay and trust in the market started to falter: a few financial specialists sold their stocks and haul out. In October, showcase dives in and froze financial specialists endeavored to dump their stocks. Dark Tuesday, October 29th, most exceedingly awful day in the emergency: individuals and enterprises hysterically endeavoring to sell their stocks before costs dove much further. As stock costs dropped, individuals were not ready to sell their stocks at a similar cost that they obtained them and were in this manner losing cash.

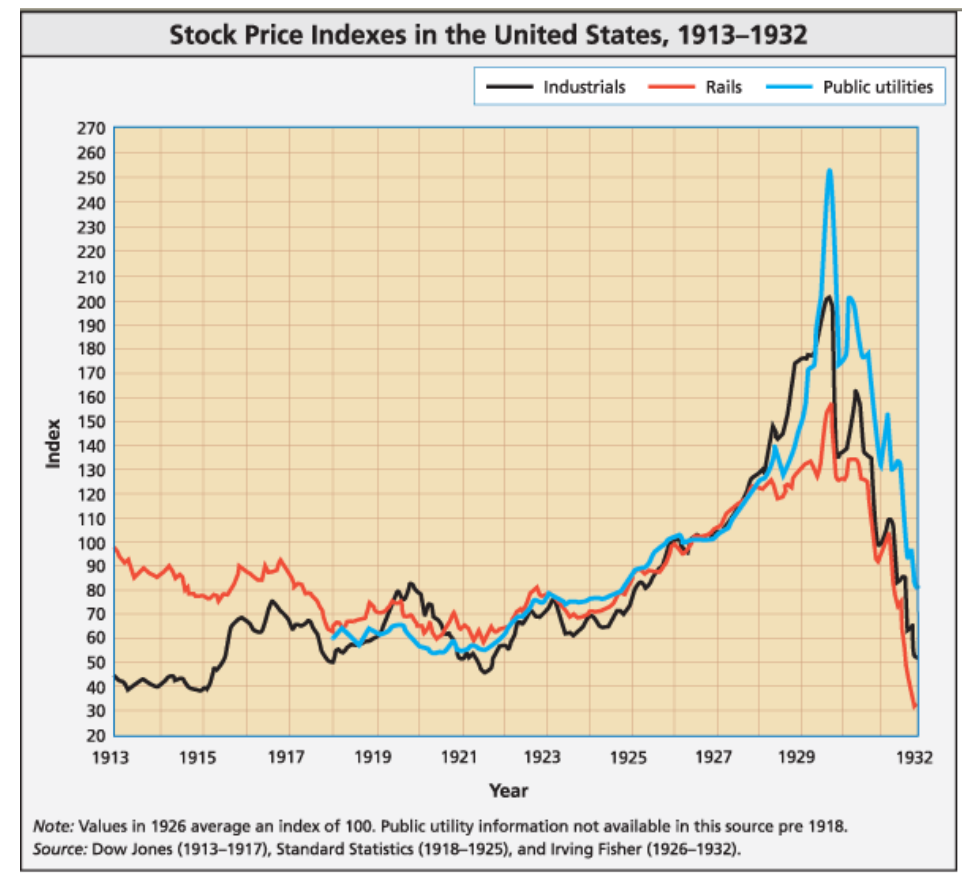

Figure1. 
Bank Failures: The economy was terribly blighted by the influences of stock market crash. As Figure 2 underneath shows, (during the period of the Great Depression, there are thousands of banks that went bankrupt, the situation of year of 1931 and 1933 were severest with nearly 2300 and 4000 banks going broke respectively. The more banks failed, the more panicked the people were, thus all of them were rushing to banks to withdraw money, which compounded the situation as more and more banks are forced to close and people are more destitute of cash, hence the situation in which less and less spending are made. The Great Depression assumed a worse scene of bleakness and sluggishness

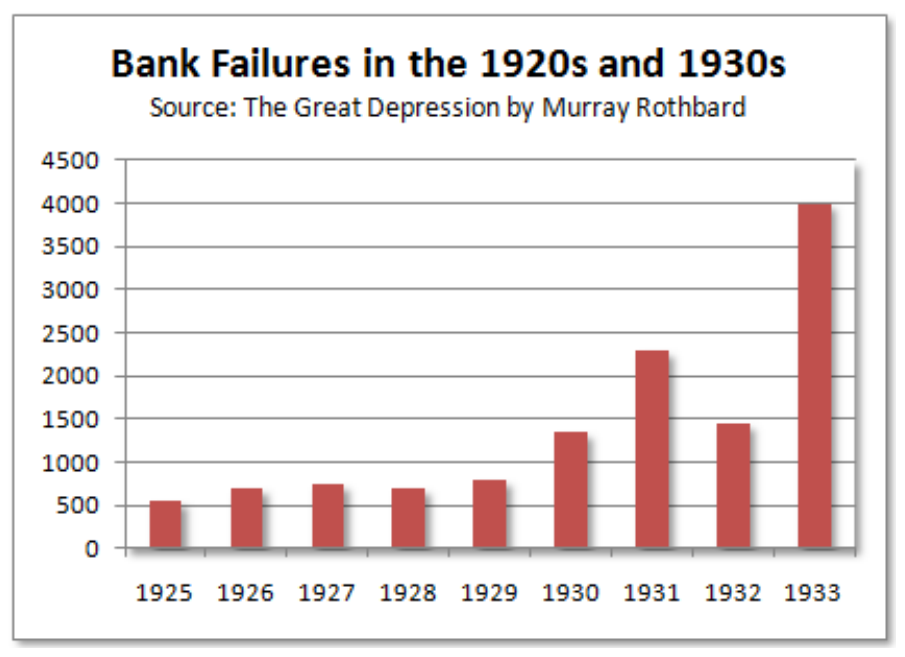

Figure2.

Wide reduction in purchasing: (as the banks failed and investments continued to lose their values so the customers' spending abilities were continuously going down at a high rate, which caused a consequence that across-the-board social demand was in a sharp decline, leading to hundreds of thousands worker being laid off by their employers as less and less customers would purchase their products. The Figure 3 below shows the employment rate in America and Canada, we can identify that in 1933, which is also the most-affected year during period of the Great depression, the unemployment was nudging nearly $25 \%$ in the USA.

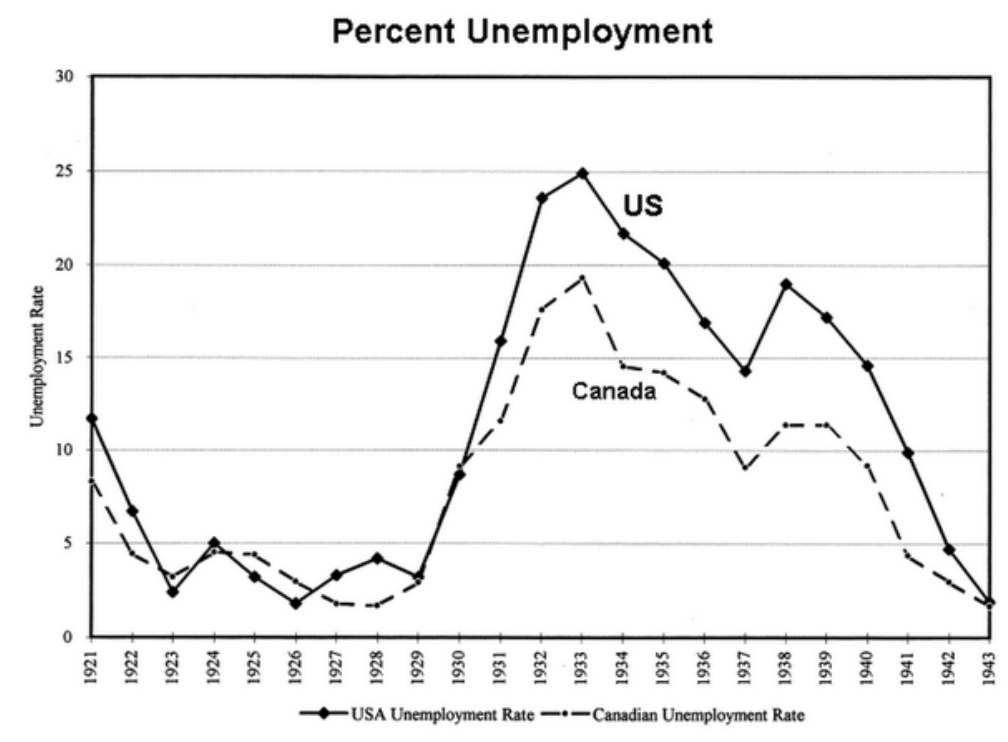

Figure3.

Drought Conditions: The period of the Great depression has witnessed a major environmental disaster-Drought that compound the economic situation. Due to the drought, a large amount of the farmland was no longer arable and farmers, to whom the land was the major source of their income, suffered a great deal, and so did a large number of farm hands who were employed by the farmers as there was not much work to do on the farm. Coupled with the crippling impacts of the Great Depression, the drought aggravated immensely the situation of the depression. 


\subsection{An Analysis on the Economic Situation Reflected from the Text}

As it is known to us that To Kill a Mockingbird set its background in the 1930s when the Great Depression was happening, hence the speculation that the economic condition in the context of Lee's work was dire as well. Through the analysis of the depictions, we can grasp the overall economic situation of the time.

In chapter 1, Lee is describing Maycomb in general. in her description, Maycomb was a quiet town without much dynamism with people moving sluggishly, and the building there were shabby. Lee then mentioned that there was "nothing to buy and no money to buy it with". (Harper Lee, 1960, P6), reflecting the dire economic situation. However, Lee says "it was a time of vague optimism for some of the people: Maycomb County had recently been told that it had nothing to fear but fear itself" (Harper Lee, 1960, P6). It is intriguing to interpreting this comment on Maycomb as it carries the connotation of historic context of the story which occurs in the early nineteen thirties. The fear is related to an inaugural speech of Roosevelt when he took office on 1933.4.4. He encouraged people to get over their fears by giving them hopes that the economic situation would finally turn a turn for the better. Despite the fact that a lot of Americans' livelihoods were at a poor level in the Depression, much of them were positive that things will get better eventually with the leadership of President Roosevelt. Nevertheless, this hope is, after all, vague optimism that hasn't been achieved yet and through Lee's depiction it's not hard to find the economic conditions are still sluggish.

In chapter 1 Lee also depicted that "boney mules hitched to Hoover carts flicked flies in the sweltering shade of the live oaks on the square."(Harper Lee, 1960, P6) It seems that an usual sketch of the country view of that time, but the term Hoover carts, in the historical context, implied the rotten legacy of Hoover administration resulting from their inability of taking effective steps to contain the Great Depression. As the historical context tells, in 1929 Herbert Hoover was elected the 31st president of the USA, when the Great Depression started to break out. However, with the Depression worsening, Hoover did not realize the seriousness under that circumstance in due course or take effective measures to keep the situation under the control. During the depression, the public was harboring a great deal of grudge against Hoover, hence the naming of things after him as a way to derogate him. This term can be a piece of evidence that people of Maycomb like all the other Americans of that time blamed and teased Hoover, at the same time it reflects the severe economic situation that was in part caused by Herbert Hoover.

\subsection{The Depression Impact Reflected from the Text}

There's no escaping the fact that the Great Depression delivered a crippling blow to the Americans and was one of the causes of their sufferings, some of which were also mentioned in Lee's works. The American South has long been famous for its fertile soils and it is hot in summer there, making it a prime location for cotton growing, and it is not difficult to recognize the connotation behind Lee's depiction that "It was customary for men in the family to remain on Simon's homestead, Finch's landing, and make their living from cotton." (Harper Lee, 1960, P4) This means a certain period of time before the Great Depression, the economic condition for cotton, compared with that of the Great Depression, was relatively good, at least, they could make their living from cotton. In terms of the economic condition for cotton we can perceive indirectly what the actual economic condition for cotton was during the Great Depression in her book since she mentioned that "John Hale Finch was ten years younger than my father, and chose to study medicine at a time when cotton was not worth growing." (Harper Lee, 1960, P5-P6) and "I never knew how old Mr. Radley made his living__Jem said he 'bought cotton,' a polite term for doing nothing." (Harper Lee, 1960, P11) These two quotes implied that they could no longer make their living on cotton. Historically speaking, it's not hard to explain the shift from living on cotton to not worth growing it. As the Depression continued to deliver its toll, Alabama's farm families were suffering greatly as cotton prices dropped greatly thus making it worthless to growing cotton as farmer could barely gain any profit.

Under that circumstance, subsequently, people, especially in a farm county like Maycomb were becoming poorer and poorer. In the book there's a short conversation among the Finch family.

“'Are we poor, Atticus?'

'We are indeed.'

Jem's nose wrinkled. 'Are we as poor as the Cunninghams?' 
'Not exactly. The Cunninghams are country folks, farmers, and the crash hit them hardest."' (Harper Lee, 1960, P27)

It is evident that the disruption of the agriculture that was stemmed in part from the Depression impinged on the farmers most, yet it also had a ripple effect on other professional people like doctors, dentist and lawyers, etc. As the protagonist's father explained, "Professional people were poor because the farmers were poor. As Maycomb County was farm country, nickels and dimes were hard to come by for doctors and dentists and lawyers." (Harper Lee, 1960, P27) One of the most affected areas was the south, on which the novel is based. During the 1930s, the Great depression, coupled with some natural disasters like pest plague and large-scale flood devastated the region's economy. Atticus make explanation to his children that farmers such as the Cunninghams are most affected, and that he earns little money so he has to uses what he does have to pay the interest. He can choose to work for the WPA (Works Progress Administration). President Franklin Roosevelt initiated this program to create more jobs for the unemployed. However, if he chooses the WPA, then he has to give up the opportunity to work on his own land, that's why although he has no money he still refuses to take the job. As a result, farmers do not have the cash to pay the professional people, like doctors or lawyers like Atticus, leading to the general poverty in the town

An idea concerning the influences of the Depression on the very town where the Finches lived has been roughly revealed through the details and hints in the book. Yet it is necessary to zoom out and pay attention to a larger scale, and to see what the impact is on other places. In chapter 12 "As if that were not enough, the state legislature was called into emergency session and Atticus left us for two weeks. The governor was eager to scrape a few barnacles off the ship of state; there were sit-down strikes in Birmingham; bread lines in the cities grew longer, people in the country grew poorer." (Harper Lee, 1960, P154-155) A sit-down strike mentioned here is one type of strike when groups of workers in factories refuse to work by sitting at somewhere due to certain reasons. The resort to sitdown strikes directly revealed the fact that workers' demands were not met, and longer bread lines means during the Depression, a large number of workers could hardly make a living, and many people were living below the level of subsistence, most of whom having to depend on the food given out in the street. These analyses show that people, whether in Maycomb or outside town, are suffering a great deal due to the impact of the Great Depression.

For Tom Robinson, his living condition seems terribly worse still, because in a dialogue between Atticus and Scout, Atticus said that Tom Robinson "lives in that little settlement beyond the town dump" (Harper Lee, 1960, P100). Although Lee doesn't give more details about his living condition, a little settlement beyond town dump is enough for us to picture a misery living condition and we can easily connect his economic suffering with the Great Depression as he is also living in the affected area. In spite of the fact that he "works pretty steady for Mr. Link Deas all year round" (Harper Lee, 1960, P255), he still lives in a small settlement hut around the town dump and lives in a poor condition due to the overwhelming impact of the Great Depression.

\section{CONCLUSION}

Based on all the analyses above, Tom Robinson's misery fate and injustice treatment could be largely contributed to the racism and the dire economic condition at that time, or the combination of the two forces consigned him to such a particular situation that he did suffer more and live a poorer life than those white counterparts. From the perspective of history and Robinson's false accusation, it is evident that the long-lasting discriminatory attitude, which has been existed since the enslavement and even after the Civil War, was generating a blatant sin_ a stereotype that black people are unreliable, suspicious and get involved in crime and various evils easily. Consequently, it's not hard to imagine that in a jury dominated by white people, the impartiality of the judge would be problematically skewed by this kind of stereotype, or even completely eliminated. And due to this kind of stereotype, Tom Robinson is destined to struggle for his living and justice, that's why his misery was inevitable and doomed in that era. It's not difficult to arrive at a conclusion that Tom Robinson was only an epitome of a larger number of poor black people in America at that time. His misery fate can be transplanted into any other black people's fate randomly. In this sense, he is just a representative of black community of that time and an innocent victim of that particular time and those particular twisted historical stresses. In light of the limited space of this paper and writer's inadequate academic ability, there are some aspects in this paper needing more polishes in future research. 


\section{REFERENCES}

[1] Harper Lee. To kill a mockingbird [M]. New York City: Grand Central Publishing. 2010.

[2] Shikha Agarwal. Reflection of American Society in Harper Lee's To Kill a Mocking Bird [J]. Imperial Journal of Interdisciplinary Research 2016(7): 975-976.

[3] Christina D. Romer. The Great Crash and the Onset of the Great Depression [J]. The Quarterly Journal of Economics, Volume 105, Issue 3, August 1990, Pages 597-624

[4] 赵茗茗, 师语聘.《杀死一只知更鸟》中的种族歧视表现 [J]. 《名作欣赏》2016(24):8-10

[5] 孟得明,李凤萍,徐坚俊. 美国种族歧视下的黑人悲剧命运——评《杀死一只知更鸟》《安徽文学》 2017(7): 40-41+44.

[6] 彭庆宸, 王嘉冬. 基于相关货币政策浅析美国大萧条发生原因[J].《知识经济》2017(14):40+42.

[7] 周莉萍. 大萧条时期美国黑人妇女就业状况探析[J]. 《历史教学问题》2013(3): 63-66+11.

[8] 刘风娟. 大萧条非裔美国人研究[D]. 上海：华东师范大学，2009.

[9] "What quotes and details from To Kill a Mockingbird relate to The Great Depression and the stock market crash of 1929?" eNotes, 14 Dec. 2015, https://www.enotes.com/homework-help/what-quotes-kill-mocking bird-great-depression-580224. Accessed 5 Mar. 2019.

[10] "What was the economy of the US during the time To Kill a Mockingbird is set?" eNotes, 29Apr.2013,https://www.enotes.com/homework-help/describe-economy-us-during-this-time-431456. Accessed 5 Mar. 2019.

[11] "What does Atticus mean when he says that professional people are poor because the farmers are poor? Harper Lee's To Kill a Mockingbird." eNotes, 3 Nov. 2009, https://www.enotes.com/homework-help/ what-does-atticus-mean-when-he-says-that-112627. Accessed 5 Mar. 2019.

[12] http://historydetectives.nyhistory.org/2015/07/reading-into-mockingbird-the-great-depression

[13] https://www.bigtrends.com/education/lessons-from-the-past-10-charts-graphs-of-the-great-depression

[14] https://www.slideshare.net/almiklas/charts-and-graphs-of-the-great-depression

[15] http://dailybail.com/home/chart-bank-failures-during-the-great-depression.html

\section{AUTHORS' BIOGRAPHY}

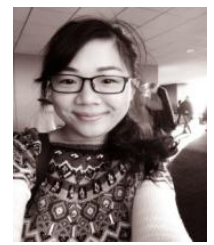

Min Zhou was born in Chengdu, China in 1984. She received her M.A. degree in English and Language Literature in Sichuan University, China and studied American Literature in University of Wisconsin, USA as a visiting scholar. She is a lecturer in School of Foreign Languages, Zhejiang Ocean Universities, China. Her researches focus on Comparative Literature and Chinese Classical Mythology

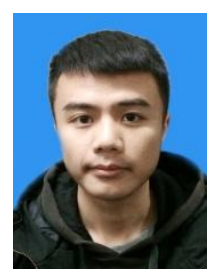

Youwen Hu was born in Lishui, China in 1997. He is currently a college student in Zhejiang Ocean University, Zhoushan, China. His research interests include business English, English literature and have strong curiosity about any interdisciplinary research possibilities.

Citation: Youwen Hu, Min Zhou. "The Root of Sin: An Analysis on the Social and Economic Situation Reflected from To Kill a Mockingbird" International Journal on Studies in English Language and Literature (IJSELL), vol 6, no. 5, 2019, pp. 48-55. doi: http://dx.doi.org/10.20431/2347-3134.0704005.

Copyright: () 2019 Authors. This is an open-access article distributed under the terms of the Creative Commons Attribution License, which permits unrestricted use, distribution, and reproduction in any medium, provided the original author and source are credited. 